\title{
Sprawozdanie z Konferencji Naukowej „Procesy i procedury: nowe wyzwania”
}

Nowy dokument papieski Mitis Iudex Dominus Iesus wprowadził nie tylko zmiany w procesie o orzeczenie nieważności małżeństwa, ale także w programie planowanej od czerwca Konferencji naukowej na Wydziale Prawa Kanonicznego Uniwersytetu Kardynała Stefana Wyszyńskiego. 22 października 2015 roku odbyło się naukowe spotkanie kanonistów, które dzięki elastyczności organizatorów idealnie wpisało się w świeżą dyskusję nad nowym papieskim dokumentem, poruszając jednocześnie problemy z zakresu kościelnego prawa administracyjnego.

Na początku Konferencji zgromadzonych gości, prelegentów oraz wszystkich uczestników przywitał gospodarz - Dziekan Wydziału Prawa Kanonicznego UKSW ks. prof. dr hab. Henryk Stawniak SDB, który życzył wszystkim owocnych obrad, które mają na celu głębsze poznanie nowego dokumentu Ojca Świętego Franciszka i jego recepcję w praktyce sądowej i duszpasterskiej, a ponadto pogłębienie wiedzy z zakresu procedury administracyjnej, stojącej niejako obok sądownictwa kościelnego, ale ściśle z nim powiązanej. Następnie w imieniu gospodarza Uniwersytetu głos zabrał ks. prof. UKSW dr hab. Maciej Bała, Prorektor do spraw studenckich i kształcenia, który otworzył obrady Konferencji.

W pierwszej sesji, której przewodniczył ks. prof. dr hab. Wiesław Wenz z Papieskiego Wydziału Teologicznego we Wrocławiu, zaplanowano cztery wystąpienia. Jako pierwszy głos zabrał dr hab. Bartosz Wojciechowski z Uniwersytetu Łódzkiego, który 
wygłosił referat „Wymogi dyskursywno-etyczne procesu sądowego". W wystąpieniu prelegent podkreślił, że komunikacja $\mathrm{w}$ formie dyskursu wymusza na instytucjach uczynienie zadość określonym wymogom norm prawnych, które przejmowane są przez teorię dyskursu. Implikując zasady prawne i moralne referent odniósł się do wymogów procesu sądowego spoglądając nań jako, $\mathrm{z}$ jednej strony, fakt normowany przez prawo, ale także przez etykę, czy moralność. Sędzia Naczelnego Sądu Administracyjnego podkreślił, że prawo jest dziedziną aktywności oraz że sędzia nie tylko jest zobowiązany do biernego wysłuchania zdania stron, ale także, zgodnie z przytoczoną przez prelegenta teorią Dworkina, „staje się pojednawcą i rzeczywistym uczestnikiem procesu argumentującego".

„Mentalność prorozwodowa a procesy małżeńskie” to tytuł wykładu ks. prof. UKSW dr. hab. Jana Krajczyńskiego. Ksiądz Profesor rozpoczą od znanego w jego sposobie uprawiania kanonistyki wytłumaczenia znaczenia pojęć, którymi będzie się posługiwał. Następnie określił stosunek Magisterium Kościoła do tak zwanej „mentalności prorozwodowej”, która jest zauważalna w wielu krajach Starego Kontynentu. Stolica Apostolska zaczęła piętnować postawę prorozwodową wśród członków Ludu Bożego już za papieża Benedykta XIV, wtórował mu Leon XII, Pius XI i wielcy papieże XX wieku; szczególnie ważnym dokumentem podkreślającym istotę życia rodzinnego opartego o jedno i nierozerwalne małżeństwo jest niewątpliwie adhortacja apostolska Jana Pawła II Familiaris consortio. Następnie Kierownik Katedry Prawa o Posłudze Nauczania WPK UKSW przeprowadził analizę wpływu mentalności prorozwodowej na kształt norm z zakresu procesów małżeńskich oraz uwidocznił problem rozwodów poprzez przedstawienie statystyki stwierdzeń nieważności małżeństwa w kontekście mentalności rozwodowej. Konkludując prelegent zaznaczył, że mentalność prorozwodowa i same rozwody stanowią poważny problem społeczny i religijny oraz zaproponował sposób rozwiązania problemów stanowiących przeszkodę do realizacji celów małżeństwa. „(...) Wzrost świadomości religijnej i utwierdzenie autentycznej relacji międzyosobowej wiernych z Panem Bogiem, w czym mogą mieć swój udział wszyscy, którzy realizują kolejne 
fazy procesów małżeńskich, w istotnej mierze wpływają na zakres mentalności sprzyjającej rozwodom. (...) Im wyższa jest świadomość religijna wiernych i im bliższe są ich więzy z osobą Boga, tym mniejsze jest prawdopodobieństwo podzielania przez nich sposobu myślenia i postępowania negującego zasadę nierozerwalności małżeństwa”.

Kolejnym prelegentem był ks. prof. dr hab. Tomasz Rozkrut z Uniwersytetu Papieskiego Jana Pawła II w Krakowie, który wygłosił referat pod tytułem „Pewność moralna niezmiennym uwarunkowaniem pozytywnego wyrokowania”. Ksiądz Profesor w swojej analizie wykazał, na podstawie nauczania Piusa XII, Jana Pawła II oraz doktryny prawa kanonicznego, że pewność moralna stanowi najbardziej fundamentalne zagadnienie dotyczące pracy sędziego kościelnego. Ponadto, konkludując, prelegent podkreślił, że stanowisko Kościoła nadal, niezmiennie podkreśla ważność pewności moralnej jako zasady wyrokowania nie tylko w procesach małżeńskich. Ksiądz Profesor zaznaczył, że „stałość oraz obowiązywalność przedstawionej zasady trzeba przypominać zwłaszcza dzisiaj, kiedy na skutek zmiany mentalności uczestników kanonicznego procesu małżeńskiego, w szczególności kiedy coraz częściej mamy do czynienia z postawą roszczeniową oraz pretensjonalnością uczestników tego procesu, jak również kiedy zanika zrozumienie istotnego przymiotu małżeństwa, którym jest jego nierozerwalność (...)”.

Ostatni z prelegentów przedpołudniowej sesji Konferencji ks. prof. KUL dr hab. Leszek Adamowicz zmienił temat swojego wystąpienia idealnie wpisując się w dyskusję nad nowym kształtem procesu małżeńskiego na mocy motu proprio papieża Franciszka Mitis Iudex Dominus Iesus. W przygotowanym i opublikowanym już artykule Ksiądz Profesor zastanawiał się nad prowadzoną reformą postępowania o stwierdzenie nieważności małżeństwa wskazując wątpliwość dotyczącą dwóch instancji procedowania. W związku z wprowadzoną reformą Ksiądz Adamowicz stwierdził, że nie ma sensu zastanawianie się nad sytuacją, która już jest, w związku z czym zaprezentował temat dotyczący wątpliwości, jakie niesie za sobą wprowadzenie w życie norm prawnych promulgowanych przez Ojca Świętego. 
Na kanwie wystąpienia Księdza Profesora rozpoczęto gorącą dyskusję, którą inicjował przewodniczący sesji ks. prof. dr hab. Wiesław Wenz. Z kolei przerwa kawowa, która wieńczyła przedpołudniowe spotkanie polskich kanonistów, była okazją do pogłębienia poruszanej problematyki i prywatnego rozwiania powstałych wątpliwości.

Popołudniowej sesji obrad przewodniczył ks. prof. dr hab. Wiesław Kiwior, Prodziekan Wydziału Prawa Kanonicznego UKSW w Warszawie. Ksiądz Prodziekan zaprosił do stołu prezydialnego trzech prelegentów drugiej sesji.

Jako pierwszy głos zabrał ks. prof. dr hab. Ginter Dzierżon z Uniwersytetu Kardynała Stefana Wyszyńskiego w Warszawie, który przygotował referat dotyczący kontrowersji związanych z figurą ciszy administracyjnej zawartej w kanonie 57 Kodeksu Prawa Kanonicznego z 1983 roku. Wykład Księdza Profesora wkraczał w tematykę dość słabo opracowaną przez polskich kanonistów, niewielu jest bowiem przedstawicieli nauki zajmujących się prawem administracyjnym Kościoła, w związku z czym cieszył się dużym zainteresowaniem słuchaczy. Ksiądz Dzierżon podkreślił, że kanon 57 ma duże znaczenie dla ochrony praw wiernych poprzez ustanowienie konkretnego terminu, przez co administracja kościelna zobowiązana jest do nieodkładania na czas nieokreślony wymaganej prawem decyzji. Ponadto, figura ciszy administracyjnej, zdaniem Księdza Profesora, może być wiązana także z prawem procesowym.

„Wadliwość merytoryczna aktu administracyjnego jako motyw rekursu sądowo-administracyjnego do Drugiej Sekcji Sygnatury Apostolskiej" to tytuł wykładu wygłoszonego przez dra Adama Bartczaka. Prelegent zauważył, że rekurs do Sectio Altera Sygnatury Apostolskiej jest poddawaniem pod osąd władzy sądowniczej decyzji władzy wykonawczej. Zwięzłe wystąpienie przedstawiciela Uniwersytetu Łódzkiego podsumowane zostało wnioskami, szczególnie interesujący jest postulat de lege ferenda zaproponowany przez Doktora Bartczaka, mianowicie o podjęcie dyskusji nad możliwością wprowadzenia wadliwości merytorycznej jako motywu rekursu sądowo-administracyjnego. 
Ostatni wykład wygłosił adiunkt Wydziału Prawa Kanonicznego ks. dr Tomasz Białobrzeski, który przeanalizował prace Papieskiej Komisji do spraw Rewizji Kodeksu Prawa Kanonicznego nad projektem ustanowienia trybunałów administracyjnych. Wiceoficjał płocki przedstawił poszczególne etapy prac nad ustanowieniem trybunałów administracyjnych, szczególnie w Papieskiej Komisji Specjalnej De Processibus, następnie w Papieskiej Komisji Specjalnej De Procedura administrativa, aż wreszcie w szerszym gremium specjalistów z zakresu prawa kanonicznego, w Papieskiej Komisji ds. Rewizji KPK. Ksiądz Doktor stwierdził, że „analiza wszystkich norm dotyczących sprawiedliwości administracyjnej pozwoliła na całościową i ogólną ocenę dostępnych środków jej zagwarantowania", stąd idea wprowadzenia lokalnych trybunałów administracyjnych nie została włączona w normy Kodeksu Prawa Kanonicznego z 1983 roku.

Dużą popularnością cieszyła się popołudniowa dyskusja, którą przeprowadził przewodniczący sesji ks. prof. dr hab. Wiesław Kiwior. Następnie wszystkich przybyłych gości pożegnał, dziękując za przybycie, główny organizator październikowego spotkania naukowego kanonistów, ks. prof. dr hab. Grzegorz Leszczyński.

Igor Kilanowski 